\title{
1956 in the Oral Tradition in Sokorópátka
}

A Review of Adél Vehrer's Book

\section{SUMMARY}

In her new book, Dr Adél Vehrer, ethnographer, associate professor and an emblematic personality of her generation in this discipline, explores the essence of the national unity created during the 1956 Hungarian Revolution and Freedom Fight, an event that also influenced international history. This review aims to highlight the correlations in this complicated process, in the hope that the book, while serving our generation, will be a curiosity in the future. The English translation of the book was published simultaneously with the Hungarian version.

Keywords: 1956 Hungarian Revolution and Freedom Fight, folk tradition

In his works, historian Elemér Mályusz focused on the development of a theoretical basis and methodology for research in ethnic characteristics. He elaborated this programme at the request of historian and ideologist Gyula Szekfú, and published it in his study entitled $A$ népiség története [The history of ethnic character] in 1931. The essence of his idea was to renew Hungarian historiography using a uniform, standard method, and to incorporate the results in historiographic summaries with interdisciplinary cooperation, including ethnography, linguistics, sociology, etc. Reliable Hungarian historiography and awareness of the national identity can only be expected if comprehensive research and processing are carried out for every settlement with a common approach. Local communities should be informed of the national events and the local conditions should be incorporated in general processes. Thus the national identity will be deeply rooted in Hungary, and changing regimes and political courses cannot easily wipe it out.

The 2016 support programme implemented by the Memorial Committee established for the 60th anniversary of the 1956 Revolution and Freedom

Dr János István Németh, Research Fellow, National Institute for Culture (nemeth.janos@nminkft.hu). 
Fight also encouraged this history writing programme. The local events of the revolution and freedom fight need to be disclosed and communities encouraged to keep the memory of those glorious days alive. As the revolutionaries' generation are passing away, we are in the very last hour to collect information through personal interviews. Adél Vehrer's book entitled 1956 in the Oral Tradition in Sokorópátka is among the achievements funded in the frame of the programme and confirms that the Memorial Committee made the right decision.

The author uses the conventional methods of ethnography to discuss the topic. She was a student of Bertalan Andrásfalvy, and still an undergraduate when her first book describing the life of Lajos Tuba of Sokorópátka was published. Her doctoral thesis was published in 2004 by Gondolat Publishers in the series Doctoral Masterpieces under the title Templomos lovagok az európai néphagyományban [Knights templar in European folklore], and became a milestone in the research of historical legends in Hungary and abroad. She published a similarly significant summary entitled Népi kultúra. Néprajzi alapismeretek. [Folk culture: the fundamentals of ethnography] in 2009.

In her new book Adél Vehrer divides the dramatic events that happened to the informants living in Sokorópátka during the 1956 revolution into three major units. The book presents the suffocating atmosphere of communist dictatorship in the $1950 \mathrm{~s}$, the second describes the revolution, and the third recalls the retaliations and prison memories after the fall of the revolution and depicts, based on personal recollections, the period up to the change of regime.
Every part of the book bears a marked imprint of anxiety: "Sixty years have passed since the earth-shattering days of the 1956 Revolution and Freedom Fight in Hungary and almost three decades since the change of regime. Yet, while reading these recollections, we feel that the first half of this period affected people's lives far more, as the individual tragedies and post-revolution ordeals crushed souls, fates and communities, while the global consequences of the changes after 1990 did not have a similarly deep impression on individual lives. Fear, deeply committed to the memory, is still concealed, more or less latently, behind the recollections of 1956 in Sokorópátka” (p. 118).

The 1950s destroyed almost every element of traditional peasant live. As a result of the complete expropriation of land without compensation and the obligatory surrender of any surpluses of all kinds of agricultural produce, the peasantry had to strenuous effort to survive and suffered the most severe humiliation. The author recorded the recollections of József Nagy, Tihamér Pintér, Zoltán Dénes, István Kovács and Lajos Büki, who took part and acted bravely in the events of the 1956 revolution in Sokorópátka and then suffered from political reprisals. Adél Vehrer has arranged the texts in an excellent dramaturgical order, interconnects the ideas in a clear style, identifies new correlations and places them in a historical perspective, compiling the interviews and documents peculiar to the era into a book that provides the reader with new information and experience.

Right from the first pages the reader has the impression of watching a wellcut, exciting and thought-provoking film. The literal quotation of the series of the 
informants' stories gradually expands our understanding of the contemporary village society, and the distress caused by defencelessness increases. The author makes us see fallible human beings, the moral fibre of the peasantry even in the most difficult situations and, sometimes, even the humorous side of life in the midst of dramatic events. In what follows a taste is given of the stories from the 1950s. "I do not remember who determined the quantities to be surrendered, but I can recall this saying: 'Part of the grain was destroyed by drought, the other part by the barge and the third part must be surrendered.' It was a cruel world! Once old Pista E. accompanied the executor, a woman who was in charge of 'sweeping the loft' [i.e. confiscating even next year's sowing seed]. My mother told her that our loft was empty but she insisted on going up. 'You can go up but then I will take the ladder away!' my mother told her... Finally, the bailiff decided not to go up" (p. 17).

Today's young and middle-aged people may know precious little about "black [i.e. illicit] pig-slaughters". The following quotation provides a glimpse of how things were going: "During the Rákosi regime 'black pig-slaughters' were made. We were not given permit to kill a pig. My dad was afraid, and I was not bold enough to apply for it either. We were scared. The moon shone into the pigsty and my dad hit the pig on the head so that it did not have the chance to let out a scream. We took the pig into the pantry and scalded it. In my grandfather's house there was a big chimney where we could smoke the pig. No one ever found out what we did" (p. 21).

As we get closer to the starting date of the revolution, recollections increasingly change, from one minute to the next, a
Wagon Factory worker, a farmer, an actor, an engine driver or a shop assistant becomes a revolutionary who stands up boldly for a morally righteous case and is ready to risk his or her life. The most exciting moments in the book are those when the informants remember the life altering moments. As almost all the people recalling the 1956 revolution in Sokorópátka commuted to Gyôr for work, they also remembered the revolutionary events in Gyôr. Several previously undisclosed findings are described in the book as a result of Dr Adél Vehrer's thorough research in public record offices and court archives. They include a description of the arrival of István Török, a tragic hero of the revolutionary events in Gyôr, at Sokorópátka in the days when the revolution was put down, his meeting with the participants of local events, and of the revolutionaries from Tatabánya, who played a key role in the "battle at Écs" and wanted to organise further resistance. The events described for the first time include the burning of compulsory grain and animal surrender and confiscation documents at the village hall, which was rigorously retaliated after the fall of the revolution. After a few months of silence, reprisals reached this formerly peaceful village located at the periphery of the county. All the informants recall retaliations in the same way. The terror machinery was cynical, cruel and unlawful in every respect, as illustrated by a brief excerpt: "They put them on a truck and transported them to Gyoor. As they were going, the truck stopped and one of them was taken off, his ass kicked, a bullet fired in the air, and they went on. The men on the truck said: 'Well, one rogue has gone.' They went on and another man was taken off. The quilted-coat men were 
militiamen, party leaders and functionaries who established this paramilitary organization and made this show... They did not shoot anybody dead but made the band frightened" (pp. 39-40).

In this machinery, courts sanctified retaliations. Adél Vehrer has filled gaps by describing the mechanism and ideological basis of judicial practice, documenting trial proceedings and publishing complete texts of original court decisions, which represent exceptional value.

The local community readmitted the young people released from prison, and in the village they did not suffer any moral or financial disadvantage to their families, relatives, friends or acquaintances. On the other hand, their integration into the society outside the village was difficult. Unforgettable stories depict these hard years spent in fear and circumspection.

In her book the author guides the reader through Sokorópátka. Owing to the dynamic and stressful text, the reader just cannot put this book down as the intention of the author achieves its objective, while she recognizes exciting relations and the dramatic nature of everyday events in the deep and the universal human message reflected in the uniqueness of the fates of people living in the village. This book can be translated into any language because readers would understand in exactly the same way the tragic of human destiny written in a suggestive manner.

It is a pleasure to see the fortunate combination of values when the profound knowledge of facts and methodology are coupled with emotional commitment. This affection is clearly recognizable in every line, as summed up in the Epilogue: "The suffering and poverty of family members without a father, with a sibling or child missing after 1956-1957 are also present in the recollections. The family and the broader community of the native land shared the consequences of cruel sentences imposed for "crimes" that had never been committed. This book is a tribute to the nameless crowd" (p. 120).

With this book Sokorópátka came within view in international science through the presentation of its dramatic past from a historical period which was crucial for the nation. The book was warmly welcomed by the villagers, occasionally in tears, and the disclosure of the events that happened in Sokorópátka has added new details to the history of the 1956 revolution. Under the guidance of the author, it leads the reader "from a brook to the vast ocean", as her motto says.

The book is supplemented with an Appendix containing numerous valuable documents and photographs. It was published in English under the title 1956 in the Oral Tradition in Sokorópátka simultaneously with the Hungarian edition so that the world can become familiar with the events that happened in Sokorópátka.

Vehrer, Adél (2017): 1956 in the Oral Tradition in Sokorópátka. Bodnár Stúdió Kft., Györ, 141 pages. 